\title{
ACCESS TO MEDICAL RECORDS WITHOUT CONSENT OF PATIENT AND THE PUBLICATION THEREOF IN THE PUBLIC DOMAIN: ISSUES OF PRIVACY, DIGNITY, FREEDOM OF EXPRESSION AND PUBLIC INTEREST
}

\author{
Tshabalala-Msimang and Medi-Clinic Ltd v \\ Makhanya \\ 20083 BCLR 338 (W)
}

Introduction

Access to the medical records of a patient is generally governed by common law principles relating to consent, applicable legislation and ethical considerations. In the normal course of events a medical practitioner or health-care establishment may not disclose/release the medical records of a patient unless the patient has consented to such disclosure/release or, in the absence of consent, there is a legal duty on the medical practitioner/health establishment, or such disclosure/release is justified in terms of a recognized ground of justification/legal defence such as statutory authority, a court order, necessity, therapeutic privilege, unauthorized administration or public interest (see Carstens and Pearmain Foundational Principles of South African Medical Law (2007) 943ff; Neethling, Potgieter and Visser Law of Delict (2005) 313, 321ff; Nell "Aspects of Confidentiality in Medical Law (unpublished LLM thesis, University of Pretoria, 2006) 12ff; Promotion of Access to Information Act 2 of 2000; National Health Act 61 of 2003; South African Law Reform Commission (SALRC), Privacy and Data Protection, Discussion Paper No 109 (Project 124) October 2005 available at www.doj.gov.za/salrc/dpapers.htm; Ethical Rules of Conduct for Practitioners Registered Under the Health Professions Act 56 of 1974 (No R717 of 4 August 2006); Jansen van Vuuren NO v Kruger 19934 SA 842 (A); C v Minister of Correctional Services 19964 SA 292 (T); and NM v Smith 20077 BCLR 751 (CC)). In essence the protection of the patient's confidentiality in terms of the common law, applicable legislation and medico-legal ethics, is an articulation of the constitutional protection of the rights to privacy ( $s 14$ ), dignity ( $s$ 10), bodily integrity (s 12) and even equality (s 9). In terms of the constitutional construction and interpretation of these rights, it is clear that these rights are not absolute but may be limited if it is justifiable and reasonable in an open and democratic society as contemplated in section 36 of the Constitution (see Currie and De Waal The 
Bill of Rights Handbook (2005) 315ff; and Hassim, Heywood and Berger Health and Democracy (2007) 30ff).

The right to privacy of one's medical records can, however, be contentious, when this right is weighed against the duty to disclose, specifically if the party seeking disclosure or release thereof, is the press claiming that disclosure is in the public interest and a manifestation of its constitutional right to freedom of expression. The boundary conditions that come into play when the right to privacy, dignity, bodily integrity and equality are pitted against the right to freedom of expression, become even more problematic when the patient whose medical records are sought to be disclosed/released by the press is a public figure, a sports star, a celebrity or, as in the present case under discussion, the South African Minister of Health.

\section{The facts}

The somewhat protracted facts of the case appear from the judgment of Jajbhay J: The first applicant is a member of the cabinet of the Government of the Republic of South Africa. She is responsible for the portfolio of national health. The second applicant is a private hospital group. One of the private hospitals that the second applicant owns is operated in the Cape Town Medi-Clinic Centre. The respondents are the editor, journalists and the owner and publisher of "The Sunday Times" newspaper respectively. During 2005 the first applicant was hospitalised and treated as an in-patient at the Cape Town Medi-Clinic on two occasions. On Sunday, 12 August 2007, the Sunday Times published an article, apparently written by the second and third respondents, that was entitled: "Manto's Hospital Booze Binge". In the article the following is inter alia alleged:

"The Sunday Times is also in possession of documents related to TshabalalaMsimang's two hospital stays in 2005. Doctors who were given the files to assess for the Sunday Times said they were shocked at the excessive use of painkillers and sleeping tablets and said the patient should not have been allowed to consume alcohol while on them. Records show that on February 11 , the night before her first operation, at $8.20 \mathrm{pm}$, the minister was handed two sleeping tablets - one from her own stock and one given to her by the clinic. The report clearly states that she also drank white wine and enjoyed her supper from Woolworths. At $11.30 \mathrm{pm}$ it is recorded that she had wine again. The following day she underwent surgery. On the night after the surgery at $7 \mathrm{pm}$, she was given her supper with wine, and was also given sleeping tablets. During the early hours of the morning she complained of pain and was given morphine. On February 13 at $7 \mathrm{pm}$ her record shows that she was drinking wine when $\mathrm{Dr}$ De Beer visited her. De Beer is an internationally renowned shoulder surgeon ... During her second admission, her records show that on March 5, a few hours before her second operation on the infected shoulder, she ordered dry white wine at $8.45 \mathrm{pm}$. On March 7 at $7 \mathrm{pm}$ the records show that the minister was having a drink with $\mathrm{Dr}$ De Beer" (emphasis as per par [7] of the judgment).

The first applicant contended that the article had contained other allegations which were either defamatory or invasive of her right to privacy and dignity. She was alarmed when she became aware of the fact that the Sunday Times had access to and was in possession of the private and 
confidential hospital records relating to her stay and treatment at the Cape Town Medi-Clinic. She further stated that she was surprised to learn this particular fact. She emphasised that she had never authorised the release of such records to anyone, including the respondents. On Monday, 13 August 2007 Dr De la Hertzog ("Hertzog"), the chairman of the second applicant, called the first applicant and spoke to her spokesperson. He was informed that the files containing the first applicant's medical records were missing from the second applicant's archives. The first applicant's spokesperson then asked Hertzog to provide a written statement to that effect. Hertzog communicated a letter addressed to the first applicant dated 13 August 2007 in which the first applicant was informed that: "we hereby confirm that we have established that the hospital records relating to your two admissions to the Cape Town Medi-Clinic during 2005 have been removed from our secure archives in an unauthorized manner. We shall be lodging a case of theft with the South African Police Services in Cape Town tomorrow morning" (see par [8]-[9] of the judgment). Thereafter, communication was shared on behalf of the applicants by their legal representatives and the respondents' legal representatives. The gist of the applicants' contention was that the possession of the private and confidential medical records by the Sunday Times and by its employees contravened section 17 of the National Health Act, Act 61 of 2003 (hereinafter "the National Health Act") and was therefore unlawful. It was requested on behalf of the applicants that these documents be handed over immediately to the legal representatives of the applicants.

The respondents' attorneys in their turn, stated that the respondents did not admit that they were in breach of section 17 of the National Health Act. They further denied that the National Health Act placed an obligation on the respondents to return any of the documents which constituted medical records. It was contended on behalf of the respondents that the respondents' article of 12 August 2007 was protected by section 16(1)(a) and (b) of the Constitution. It was strenuously contended on behalf of the respondents that "there is a great public interest in publication of the allegations in the respondents' article of 12 August 2007 and this public interest overrides any entitlement, that the applicants may otherwise have had, to the relief sought" (see par [11] of the judgment]. In an attempt to indicate that the publication was justified by the public interest in the information published, it was further contended on behalf of the respondents that the following background facts have also to be considered: (a) constitutional provisions relating to the freedom of the press and other media; (b) the first applicant's responsibilities as a cabinet member responsible for the portfolio of national health; (c) the oath taken by the first applicant in terms of section 95 of the Constitution whereby she swore, inter alia, that she would "obey, respect and uphold the Constitution and all other laws of the Republic of South Africa; and hold her office as Minister with honour and dignity"; (d) the political responsibilities of the first applicant who is politically responsible for the administration of the Department of Health in terms of the Constitution; (e) the first applicant's meeting during January 2003 with provincial members of the executive committees for health in the nine provinces in South Africa with a view to "intensify the health campaign 
against alcohol and substance abuse as one major factor behind many health and social problems in the country"; (f) the many meetings convened by the first applicant as well as the seminars and conferences that she attended where health regeneration was promoted; (g) the article printed in the Sunday Times on 19 August 2007 which included the fact that the first applicant "had alcoholic liver disease caused by years of excessive drinking" before her liver transplant in early 2007. This, according to the respondents, was received from the general public. It was further emphasised that the first applicant had not ceased drinking alcohol before the transplant, or after the transplant. It was argued accordingly that the first applicant ought not to have been given a transplant; (h) that the first applicant was convicted of theft in the Republic of Botswana; and (i) the conduct of the first applicant at many meetings is also set out with reference to the acrimony that existed between the first applicant and her then Deputy Minister of Health as well as the proposed policies on HIV/Aids that have been termed as "extremely controversial" (see par [12] of the judgment).

\section{The judgment}

\section{The issues}

Jajbhay $\mathrm{J}$ crisply summarised the issues in the case by observing that in this matter the applicants have instituted an application against the respondents in order to secure the delivery of copies of the first applicant's medical records regarding her stay at the second applicant's Cape Town hospital. They further seek an interdict to restrain the respondents from further publishing or commenting on these records and from gaining the hospital records or any other private or confidential information concerning the first applicant's medical condition and/or treatment. They also seek relief requiring the respondents to destroy all reference to the aforesaid records in their respective notebooks and computers. The respondents acknowledged that they were in possession of the first applicant's medical records pertaining to her stay at the second applicant's hospital in 2005. However, on behalf of the respondents it was submitted that "so germaine are the allegations of alcohol abuse to the first applicant's fitness for office, that they are not confidential and that such access is justified by the great public interest in the information published" (see par [5] of the judgment).

In addition the court ruled that a close reflection of the papers reveal that it is not disputed that the first applicant was a patient in a health establishment owned and controlled by the second applicant. That the records containing information relating to the first applicant's health, including her health status, treatment and stay at the establishment were kept at the Cape Town MediClinic and that the records were in fact stolen from Cape Town Medi-Clinic (see par [14] of the judgment). 


\section{Application to strike out}

It is to be noted that at the hearing an application was made on behalf of the applicants for striking out several of the paragraphs that were incorporated in the respondents' affidavits. It was contended that these paragraphs contained allegations which were irrelevant, vexatious, scandalous, and inadmissible hearsay evidence. It was further contended that the respondents' papers were voluminous. However, their defence was really capable of being captured in a few paragraphs. It was contended on behalf of the applicants that the respondents abused the opportunity to file the answering affidavit and, in so doing, they "put up all manner of irrelevant, vexatious and scandalous material that has no bearing on the issues to be decided by this court" (see par [17] of the judgment).

The Court dealt with this application in terms of Rule 6(15) of the Uniform Rules of Court but observed that the said paragraphs referred to dealt with the conduct of the first applicant during her stay at the Cape Town MediClinic, as well as other related matters. The respondents contended that they were not contravening the relevant provisions of the National Health Act because the information that was gleaned from the records was in the public interest and therefore published. They further stated that there is a debate in South Africa at present as to whether or not the first applicant is a fit occupant of the high office that she presently holds. This debate they contended is presently being conducted in public in the columns of newspapers and on radio. They further stated that it is also discussed by ordinary citizens in the course of ordinary social interaction. In the circumstances of the present matter, the Court ruled that the allegations which were made did not constitute irrelevant, vexatious or scandalous matter. The Court found that these allegations are necessary for the respondents to set out in greater detail what their response was in respect to the case made out by the applicants. Of significance is the Court's ruling that the defence of public interest raised by the respondents entails a recognition of a constitutional importance of the rights to freedom of expression and to receive and impart information and ideas, now entrenched in section 16 of the Constitution. The Court further remarked that it was in this context that one will have to determine whether the first applicant's privacy was indeed invaded and that the defence raised by the respondents did disentitle the first applicant to her remedy. The Court ruled that under these circumstances it was satisfied that the said allegations are not irrelevant, vexatious or scandalous and consequently the application to strike out was dismissed.

\section{Access to health records}

The Court then proceeded to deal with the legal framework for the access to health records and the protection of confidentiality and privacy. In this regard the Court analyzed and interpreted the relevant sections of the National Health Act: section 2 (the Objects of the Act); section 14 (confidentiality), section 15 (access to health records) and section 17 (protection of health 
records). The Court accordingly found that it was clear that in terms of the National Health Act the medical records of a person are private and confidential, and stated the general rule that where a person acquires knowledge of private facts through a wrongful act of intrusion, any disclosure of such facts by such person or by any person, in principle, constitutes an infringement of the right to privacy (see par [26] of judgment]. The Court further observed that in terms of the Constitution as well as the National Health Act, the private information contained in the health records of a user relating to the health status, treatment or stay in a health establishment of that user is worth protecting as an aspect of human autonomy and dignity. This in turn includes the right to control the dissemination of information relating to one's private medical health records that will definitely impact on an individual's private life as well as the right to the esteem and respect of other people. Of significance in the present judgment is the Court's adherence to the value of specifically human dignity as foundational in our Constitution to be jealously guarded and protected (see the Court's reliance on the judgments in NM $v$ Smith supra; $S$ v Makwanyane 19953 SA 391 (CC); and Bernstein v Bester NO 19962 SA 751 (CC) - see par [28]-[31] of the judgment).

Ultimately the Court ruled that in the present matter, the respondents have not been able to show that they have not contravened the National Health Act and that their continued access of the health records of the first applicant did not result in a continuous contravention of the provisions of the National Health Act. In fact, the contravention of the National Health Act by the respondents had on these papers been established. The Sunday Times did not have any right to the medical records of the first applicant, either to possess or otherwise to have access to them. It also did not have a right to retain any copies of such records or any part thereof. In fact, in terms of the National Health Act these records are to be kept and maintained by the second applicant and access to these records is only permitted in very strict circumstances. It is the first applicant who has the right to authorize access or to deny such access. The Court reiterated that it is generally the user under the relevant provisions of the National Health Act that has a right to determine who obtains access to her health records and to information relating to her health status, treatment and stay as a patient in a health establishment. Since the records contain private and confidential information of the first applicant (including information on her health status, treatment and stay in the Cape Medi-Clinic) she is entitled to claim that those who are not authorized to have access, return it to either the first applicant or the second applicant (see par [33] of the judgment).

\section{Restraining the freedom of the press}

A significant dimension of the judgment relates to the view of Jajbhay $\mathrm{J}$ with regard to restraining the freedom of the press. It was observed that when one is dealing with a case where the information sought for publication is obtained by unlawful means, there may well be overriding considerations of public interest which would permit its publication. In this regard the 
applicants had requested that the respondents should be "interdicted from further commenting on or publishing any comment". Commenting on this relief sought by the applicants, the Court stated that the freedom of the press is celebrated as one of the great pillars of liberty. It is entrenched in our Constitution, but it is often misunderstood. Freedom of the press does not mean that the press is free to ruin a reputation or to break a confidence, or to pollute the cause of justice or to do anything that is unlawful. The Court opined, however, that freedom of the press does mean that there should be no censorship. No unreasonable restraint should be placed on the press as to what they should publish. It was further stated that, as a general matter, any person is likely to feel violated, harmed and invaded by the publication of unlawfully obtained information. Any reasonable person would probably feel less concerned if their discussions of an upcoming metropolitan council election, or the state of the global economy was unlawfully intercepted and subsequently published, than that person would if their discussion of intensely private matters such as family disputes or medical records were illegally intercepted and published for a larger audience. Similarly, the Court ruled, on the public interest side of the equation, the public will certainly be interested and accordingly benefit from discussion of matters which are clearly in the public interest (see par [36] of the judgment).

In particular it is to be noted what Jajbhay $\mathrm{J}$ stated with regard to the understanding of the concept of "public interest":

"Public interest is a mysterious concept, like a battered piece of string charged with elasticity, impossible to measure or weigh. The concept changes with the dawn of each new day, tempered by the facts of each case. Public interest will naturally depend on the nature of the information conveyed and on the situation of the parties involved. Public interest is central to policy debates, politics, and democracy. While it is generally acclaimed that promoting the common well-being or general welfare is constructive, there is little, if any, consensus on what exactly constitutes the public interest" (own emphasis as per par [37] of the judgment).

The Court consequently dealt with the Constitutional provision (s 16(1)(a) and (b)) dealing with freedom of expression in context of the right that the public has to be informed of current news and events concerning the lives of public persons such as politicians. In addition, an analysis was made of relevant case law pertaining to the issues at hand with particular reference to National Media Ltd v Bogoshi 19984 SA 1196 (SCA). In reliance on this case, the Court resolved that the enquiry in the present case envisages recognition of the constitutional importance of the rights to freedom of expression and to receive and impart information and ideas, entrenched in section 16 of the Constitution. The Court followed the ruling of the Supreme Court of Appeal in Bogoshi where these two competing constitutional rights come into conflict, that is, the right to freedom of expression and the right to dignity. In that case the Supreme Court of Appeal stated that, where two competing constitutional rights come into conflict - each invoked by different parties, and seeking to intrude on the other's right - a court must reconcile them. Constitutional rights have equal value and therefore this reconciliation is achieved by recognising a limitation upon the exercise of one right to the extent that it is necessary to do so in order to accommodate the exercise of 
the other according to what is required by the particular circumstances and within the constraints that are imposed by section 36 of the Constitution. In other words, one weighs the extent of the limitation against the purpose, importance and effect of the intrusion and this entails weighing the benefit that flows from allowing the intrusion against the loss that said intrusion will entail. In addition, the Court dealt with another recent ruling of the Supreme Court of Appeal in Midi Television (Pty) Ltd v Director of Public Prosecutions, Western Cape (2007 2 SACR 439 (SCA)), where it was stated that "a publication will be unlawful, and thus susceptible to being prohibited, only if the prejudice that the publication might cause to the administration of justice is demonstrable and substantial and there is a real risk that the prejudice will occur if publication takes place. Mere conjecture or speculation that prejudice might occur will not be enough. Even then publication will not be unlawful unless a court is satisfied that the disadvantage of curtailing the free flow of information outweighs its advantage". The Supreme Court of Appeal held that the reason for this was that it is not merely the interests of those associated with the publication that need to be brought to account but, more important, the interests of every person in having access to information (see par [43] of the judgment).

In the present matter, the Court resolved, what had to be weighed was the extent of the limitation of the first applicant's rights against the benefit that flowed from allowing the intrusion of the right to receive and impart information in section 16(1)(b) of the Constitution. The respondents have set out in the answering affidavit the reasons why there will be a benefit in allowing a free flow of information, and which of the revelations made were relevant to the first applicant's performance of her constitutional and ministerial duties and were therefore in the public interest. Therefore, the Court ruled, the respondents should not be prohibited from further commenting in this matter.

Of particular significance is the stance of the Court with regard to the status and person of the first applicant in the public domain. In this regard the Court stated that in her capacity as a Minister the first applicant cannot detract from the fact that she is a public figure. In such a case her life and affairs have become public knowledge and the press in its turn may inform the public of them. The Court found that much of the information that was published was already in the public domain. Here the information although unlawfully obtained, went beyond being simply interesting to the public; there was in fact a pressing need for the public to be informed about the information contained in the medical records of the first applicant. Then, the disclosure made by the Sunday Times did not mislead the public about an issue about which the public has a genuine concern. And finally, the publication of the unlawfully obtained controversial information was capable of contributing to a debate in our democratic society relating to a politician in the exercise of her functions (see par [45]-[46] of the judgment).

The Court, once again invoked the approach in Bogoshi supra and observed that this approach has two principal virtues. Firstly, it seeks to harmonise as much as possible respect for human dignity and freedom of 
the press, rather than to rank them in terms of precedence. Secondly, by stressing the need for the media to take reasonable steps to verify the information to be published, it introduces objective standards that can be determined in advance by the profession and then evaluated on a case by case basis by the courts. The result is the creation of clearly identifiable and operational norms, and the fostering in the media of a value of care and responsibility (see par [49] of the judgment).

In conclusion the Court stated that this was a case where the need for the truth is in fact overwhelming. Indeed, the Court remarked, in this matter the personality involved as well as her status establishes her newsworthiness. Here, one is dealing with a person who enjoys a very high position in the eyes of the public and it is the very same public that craves attention in respect of the information that is in the hands of the Sunday Times. The overwhelming public interest points in the direction of informing the public about the contents incorporated in the medical records in relation to the first applicant, albeit that the medical records may have been unlawfully obtained. In these circumstances the Court ruled that it could not accede to the requests of the applicants with regard to paragraphs 3 and 7 of their notice of motion which in effect would impose a form of censorship in relation to any future publication around the medical record (see par [51] of the judgment).

\section{Judicial comment on the conduct of journalists and the issue of costs}

Jajbhay $\mathrm{J}$ was at pains to point out that this decision had not been concluded easily. The Court stated that the difficulty was compounded when two competing constitutional rights come into conflict, one right must suffer. Thus, the first applicant must suffer the limitation of her right to privacy. However, the Court observed, within all the euphoria and outcry against the conduct of the first applicant, she does enjoy support, and stated that just because one possesses rights, does not mean that one must exercise them to the hilt at every opportunity. Though one enjoys the freedom of expression, one would be ill advised to celebrate them by vilifying each other on the slightest pretext. In this regard the Court reiterated that journalists should be cautious when using information that is tainted with criminal activity. In addition the Court ruled that it is an integral part of the professional standards of journalists to respect the right to privacy and human dignity of the individual. It was also observed that newspapers, no less than other players in our society must keep in mind the consequences of their activities, and those involved with the present stories should have thought long and carefully about suitable alternatives before they chose to release this information. The Court stated that it was to be noted in this regard that it was common cause that the records were not lawfully obtained by the Sunday Times, and that this also resides in the realm of the public interest. The Court also referred to the possibility of a crime having been committed in contravention of section 17 of the National Health Act and that this was being investigated by the prosecuting authorities. Consequently the 
Court ruled that an order for costs should be granted against the respondents jointly and severally, as they were in possession of medical reports concerning the first applicant, which to their knowledge was unlawfully obtained. They acted in contravention of the National Health Act by making unauthorized copies. This sort of conduct the Court could not condone. Ultimately a ruling was made that it was proper that the respondents be ordered to pay the costs of the application (see par [52]-[59] of judgment).

\section{$4 \quad$ Assessment}

It is submitted that the decision in this case is in many respects a sterling judgment in terms of the multi-layered approach applied by Jajbhya $\mathrm{J}$ in adjudicating what must have been a legally taxing and controversial case in terms of the high public profile of the parties to the suit and the sensational dimension thereof in context of the public domain. A multi-layered approach refers to the harmonization and synchronisation of the applicable legal principles in terms of the supreme Constitution, the common law, applicable legislation (in this case the relevant principles of the National Health Act) and even ethical considerations (compare the discussion by Carstens and Pearmain $7 \mathrm{ff}$ ). It is to be noted that the Court from the outset of the judgment sets the tone which resonates throughout with reference to section 1 of the Constitution and the value system based on the culture of ubuntu. This value system and "constitutional underpinning" form an essential foundation and backdrop for the understanding and application of the right to privacy, dignity, autonomy and freedom of expression. In this regard the judgment cannot be faulted and serves as a shining example of post-constitutional jurisprudence which is truly transcendental in its normative nature as it bridges the traditional divide between private and public law.

Undoubtedly the judgment is one of those rare decisions which was apparently welcomed equally by the applicants and the respondents, for while it offers a strict grundnorm for the mandatory protection for the maintenance of the privacy and confidentially of medical records, it simultaneously offers a significant lifeline for freedom of speech and the sanctity of the public interest. In context of the violation of the first applicant's privacy and dignity "the die was cast", as it were, by the fact that the medical records were obtained unlawfully by the respondents and subsequently, in terms of the said normative approach, there is no other option but to sanction them legally. On the other side of the coin, the Court correctly acknowledged that it cannot judicially enforce censorship and shield the Minister of Health from public scrutiny and censure. This somewhat precarious balance and tension between the right of privacy of a public figure tainted with controversy on the one hand, and the freedom of the press and the public interest on the other hand, pose interesting hypothetical speculation from a legal perspective based on the outcomes and ratio decidendi of this case. Although the judgment admirably deals with the right to privacy, dignity and freedom of expression, it does not directly address the counter-question to these rights, namely when will there be a duty on a 
physician or the press to disclose medical records or private/confidential medical information in the public interest without the consent/authorisation of the patient? How would these rights be balanced and reconciled in a scenario, hypothetically speaking, where one for instance had a minister of health who is publicly on record as an HIV/AIDS denialist and oppose to any form of antiretroviral treatment, but who is himself/herself also, hypothetically speaking, suffering from HIV/AIDS and has secretly been taking antiretroviral treatment for years, although this information is only known to the minister's attending/personal physician? Is there then a duty on the physician to disclose this information without consent? If the press gets hold of this information/medical records may they publish without the patient's consent in the name of freedom of the press and the public interest? What about another example of a prominent political leader who is suffering from some form of brain pathology which causes him/her to be unfit for public office? Should his/her attending physician, who is aware of the medical condition, disclose this information to the press without authorisation where the political leader refuses to resign? (See in this regard Franz "Siektebeelde in 'n Wêreldstryd (Die Patologie van Leierskap)" 1995 Geneeskunde 25; compare Jansen van Vuuren $v$ Kruger supra; Tarasoff $v$ Regents of the University of California 83 ALR 3 rd 1166 (Cal 1976)). Should the right to privacy and dignity then be limited on account of the ground of justification of necessity? Or should the press, having been alerted to the state of affairs, first formally request access to the information in terms of the Promotion to Access of Information Act, and only when the request is refused then obtain a court order? One inevitably comes back to the yardstick of the "public interest", so aptly defined by Jajbhay $\mathrm{J}$ as a "battered piece of string charged with elasticity, impossible to measure or weigh - mysterious indeed"!

In conclusion, the judgment is to be welcomed as an important and influential addition to medical law, the law of delict, constitutional and human rights law.

PA Carstens

University of Pretoria 